\title{
Effect of Supplementary Light Source on Quality of Grafted Tomato Seedlings and Expression of Two Photosynthetic Genes
}

\author{
Hao Wei ${ }^{1,+}$, Jiangtao Hu ${ }^{1,+}$, Chen Liu ${ }^{1}$, Mengzhao Wang ${ }^{1}$, Jin Zhao ${ }^{1}$, Dong Il Kang ${ }^{1}$ (D) and \\ Byoung Ryong Jeong 1,2,3,* \\ 1 Department of Horticulture, Division of Applied Life Science (BK21 Plus Program), Graduate School of \\ Gyeongsang National University, Jinju 52828, Korea; oahiew@gmail.com (H.W.); \\ jiangtaoh@yahoo.com (J.H.); liuchen5281@163.com (C.L.); meng.zhao@163.com (M.W.); \\ jzhao9006@gmail.com (J.Z.); kinll900601@gmail.com (D.I.K.) \\ 2 Institute of Agriculture \& Life Science, Gyeongsang National University, Jinju 52828, Korea \\ 3 Research Institute of Life Science, Gyeongsang National University, Jinju 52828, Korea \\ * Correspondence: brjeong@gmail.com; Tel.: +82-010-6751-5489 \\ + These authors contributed equally to this work.
}

Received: 25 August 2018; Accepted: 25 September 2018; Published: 28 September 2018

\begin{abstract}
Supplementary lighting is commonly used in high-quality seedling production. In this study, grafted tomato seedlings were grown for 10 days in a glasshouse with 16-h daily supplementary lighting at $100 \mu \mathrm{mol} \cdot \mathrm{m}^{-2} \cdot \mathrm{s}^{-1}$ PPFD (Photosynthetic photon flux density) from either high-pressure sodium (HPS), metal halide (MH), far-red (FR), white LEDs (Light emitting diodes) (W), or mixed LEDs $\left(\mathrm{W}_{1} \mathrm{R}_{2} \mathrm{~B}_{1}\right.$, where the subscript numbers indicate the ratio of the LED chips) to determine which light sources improve the seedling quality. The control seedlings did not receive any supplementary light. Physiological parameters and the expression of genes related to photosynthesis were analyzed. The results showed that root length, biomass, number of leaves, chlorophyll (SPAD), scion dry weight to height ratio (WHR), and specific leaf weight (SLW) were the greatest for grafted seedlings grown in $W_{1} R_{2} B_{1}$. The level of root ball formation was the greatest for seedlings grown in $W_{1} R_{2} B_{1}$, followed by those grown in W, HPS, and MH. Seedlings grown in FR did not fare well, as they were very thin and weak. Moreover, the expression of two photosynthetic genes ( $P s a A$ and $P s b A$ ) was significantly increased by $W_{1} R_{2} B_{1}$ and $W$, which suggests that the plastid or nuclear genes might be regulated. The overall results suggest that $W_{1} R_{2} B_{1}$ was the most suitable light source to enhance the quality of grafted tomato seedlings. The results of this study could be used as a reference for seedling production in glasshouses, and may provide new insights in the research on lights affecting the development of plants.
\end{abstract}

Keywords: WHR; SLW; PsaA; PsbA

\section{Introduction}

Seedling production is the basis of most agricultural, especially horticultural, cultivation and is a main aspect of crop production, as the quality of seedlings directly affects the quality and yield of crops after transplanting. The scale of seedling production in Korea has increased gradually and significantly; in particular, the proportion of grafted seedlings of fruit vegetables is becoming increasingly important. The quality of grafted vegetable seedlings is valued by famers much more than before; thus, the quality of grafted seedlings of fruit vegetables has become a subject that deserves attention. 
Light is an essential environmental factor affecting the growth and development of plants. It not only provides basic energy to plants, but also plays a key role in their development [1-3]. Light quality refers to the composition of light with respect to the wavelengths that are effective in photosynthesis, which has a significant influence on plant morphology [4]. Since light intensity changes over the course of a day as well as with seasons on different timescales, unstable light environments might worsen the light conditions for plant cultivation. Especially in winter and rainy periods in summer, natural light is often insufficient to induce the maximum growth and development of plug seedlings in greenhouses, which leads to a prolonged cultivation time and unexpected delays in delivery to growers in Korea. Providing supplementary artificial lighting to plug seedlings may be a solution to this problem. Therefore, a study on the effects of the supplementary light quality on the development of seedlings can provide practical guidance for the effective production of high-quality seedlings.

Fluorescent lamps (FL), high-pressure sodium lamps (HPS), metal halide lamps (MH), and light emitting diodes (LEDs) are widely used in glasshouses to aid the production of grafted seedlings $[5,6]$. FL are the cheapest light source with a long working life (about 12,000 h) and a relatively low energy requirement, and are commonly used in plant tissue culture. However, FL emit a large amount of green light, which is not efficiently absorbed for plant photosynthesis. HPS have a high luminous efficiency, high power, and a long working life (about 12,000 h), and emit a high level of red (R) light and low levels of blue (B) and green (G) light. The standard sodium vapor pressure of HPS is about $10 \mathrm{kPa}$. Despite their operational benefits, because HPS are a thermal light source, the surface temperature is too high for plants [7]. MH are a discharge lamp filled with metal halides, mercury, and argon. The light emission is accomplished by the combination of electrons with ionized metal atoms [8]. Different spectra can be obtained by changing the composition of $\mathrm{MH}$. The variability of the spectrum and a high luminous efficiency make $\mathrm{MH}$ one of the most commonly used light sources in glasshouses. However, damaged or neglected MH can pollute the environment with their mercury content. On the other hand, LEDs have recently been widely applied in plant production, as they have the benefits of small size, long life, narrow spectral output, low mass, and low energy consumption $[9,10]$. Moreover, as a solid light source, LEDs do not pollute the environment. Due to their advantages, LEDs are widely used in Holland, Korea, Japan, and United States among other countries, especially due to the fruitful research on high-power LEDs in recent years [11,12].

$P s a A$ and $P s b A$ respectively encode the core components of photosystem I (PS I) and photosystem II (PS II). The expression of $P s a A$ and $P s b A$ is regulated by plastid-encoded RNA polymerase, which is recruited by light signal [13]. The expression of $P_{s} a A$ and $P s b A$ proteins can be enhanced by $\mathrm{R}$ and $\mathrm{B}$ lights [14]. Moreover, the synthesis and degradation of the $P s b A$ protein are light-regulated $[15,16]$. Most importantly, the deletion of PsaA and PsbA in tobacco (Nicotiana tabacum cv. Petit Havana) results in a simultaneous change of genes located in both the nucleus and the chloroplast [17]. Therefore, the light-dependent regulation of $P s a A$ and $P s b A$ can help explain the differences in growth and development of plants.

This study was carried out to determine the most effective supplementary light source in the quality improvement of two cultivars of tomato (Solanum lycopersicum L.), namely, Super Sunload and Super Dotaerang, which were grafted onto "B-Blocking" tomato rootstocks. Seedlings were grown for 10 days in a glasshouse with an average daily maximum light intensity of $490 \mu \mathrm{mol} \cdot \mathrm{m}^{-2} \cdot \mathrm{s}^{-1}$ PPFD coming from the sun, and a 16-h daily supplementary lighting at $100 \mu \mathrm{mol} \cdot \mathrm{m}^{-2} \cdot \mathrm{s}^{-1} \mathrm{PPFD}$ from either HPS, MH, FR, white LEDs (W), or mixed (W:R:B = 1:2:1) LEDs $\left(W_{1} R_{2} B_{1}\right)$. The control $(C K)$ did not receive any supplementary lighting. The growth parameters and photosynthesis-related genes of the seedlings were assessed to determine the effects of the different light sources on the grafted tomato seedlings. 


\section{Materials and Methods}

\subsection{Plant Materials}

Commercially available grafted seedlings of two cultivars of tomato (Solanum lycopersicum L.) were obtained from Green Plug Seedling Company (Haman, Korea). Super Sunload (Sakata Korea Co., Ltd., Seoul, Korea) and Super Dotaerang (Koregon Co., Ltd., Anseong, Korea) seedlings were grafted onto "B-Blocking" (Takii Korea Co., Ltd., Seoul, Korea) tomato rootstocks. Seedlings were all grown in 40-square-cell plug trays containing a commercial medium (Super Mix, NongKyung Co., Jincheon, Korea). The two genotypes were selected because these two cultivars are extensively used for grafting in the Republic of Korea because of their high ratio of seed germination and fruit quality.

\subsection{Grafting Procedures}

The cleft grafting method was used to graft the tomato seedlings (Figure 1) [18]. In brief, rootstock seedlings were decapitated and a 1.0-1.5-cm-long, 3/4-stem-diameter-deep longitudinal cut was made in a downward direction. For the scion chosen for grafting, 1-3 true leaves were kept on it. A tapered wedge was made with a slant angle that was cut in the lower stem. When the scion was put into the split on the rootstock, a clip was used to hold them in position until the grafted union healed.

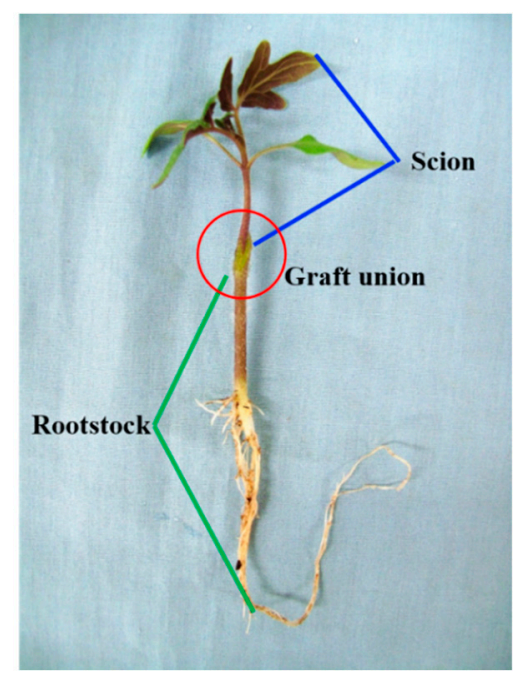

Figure 1. Grafting method used for tomato plug seedlings.

\subsection{Light Treatments}

The well-healed grafted seedlings were grown for 10 days in a glasshouse with an average daily light integral (DLI) of $14.87 \mathrm{~mol} \cdot \mathrm{m}^{-2} \cdot \mathrm{d}^{-1}$ (average daily maximum light intensity of $490 \mu \mathrm{mol} \cdot \mathrm{m}^{-2} \cdot \mathrm{s}^{-1}$ PPFD) coming from the sun, and a 16-h daily supplementary lighting at $100 \mu \mathrm{mol} \cdot \mathrm{m}^{-2} \cdot \mathrm{s}^{-1}$ PPFD from either HPS (HLF020600, BLV Licht Co., Ltd., Steinhöring, Germany), MH (SLMH-400, Sunlumen Co., Ltd., Gyeongju, Korea), FR (PAR38IR, Philips Lighting, Amsterdam, The Netherlands), white LEDs (W) (GOLED11/12, Victory Lighting Co., Ltd., Seoul, Korea), or mixed (W:R:B = 1:2:1) LEDs $\left(W_{1} R_{2} B_{1}\right)$ (Custom made, SungKwang LED Co., Ltd., Incheon, Korea) to analyze which light source most improves the seedling quality. The control (CK) did not have supplementary lighting. The spectral quality of each supplementary light treatment is shown in Figure 2. The cultivation environment had $30{ }^{\circ} \mathrm{C} / 25{ }^{\circ} \mathrm{C}$ day/night temperatures, $80 \% \pm 5 \% \mathrm{RH}$, and a 14-h natural photoperiod. The spectral distributions were measured with a portable spectroradiometer (Spectra Light ILT 950, International Light Technologies, Inc., Peabody, MA, USA). 

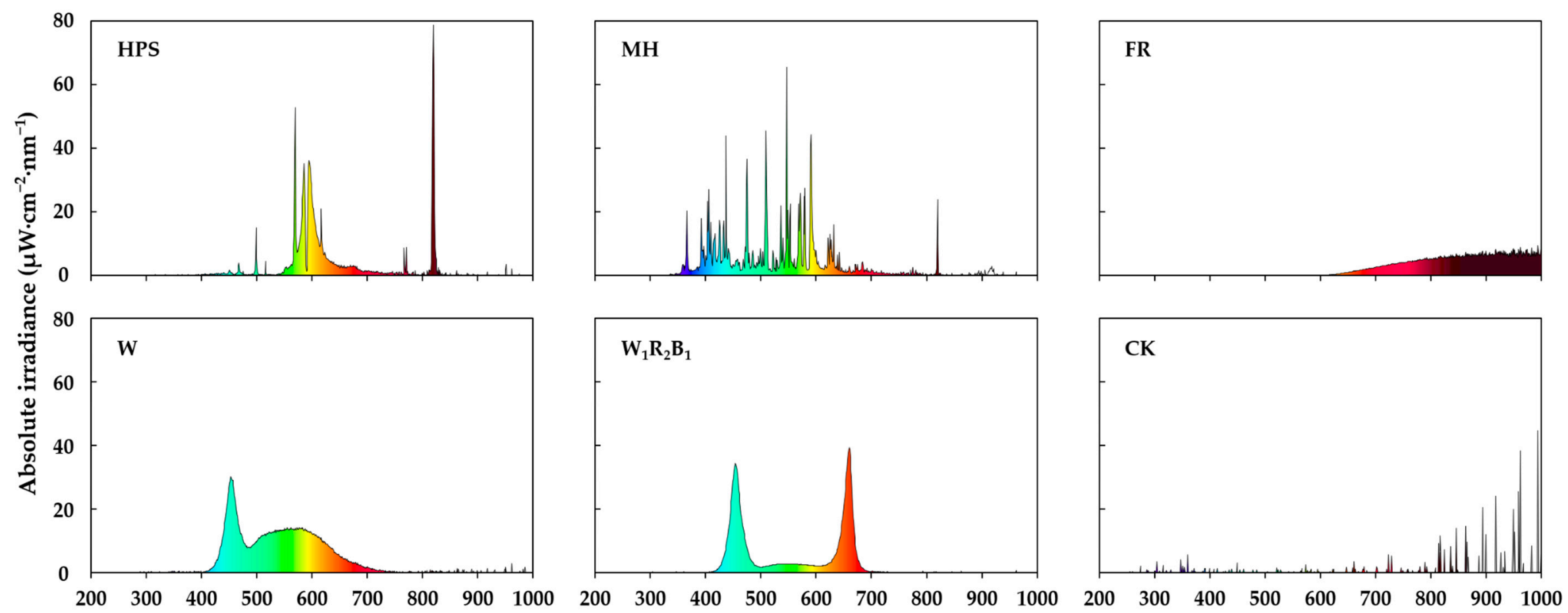

Wavelength (nm)

Figure 2. Spectral qualities of the different supplementary light sources used in the experiment. HPS (high-pressure sodium), MH (metal halide), FR (far-red), W (white LEDs), $\mathrm{W}_{1} \mathrm{R}_{2} \mathrm{~B}_{1}$ (mixed LEDs), and CK (control). 


\subsection{Data Collection and Analysis}

After 10 days of supplementary light treatments, the length of the scion and root, scion diameter, chlorophyll level (SPAD), fresh and dry weights of the scion and root, number of leaves per seedling, leaf length and width, leaf thickness, specific leaf weight (SLW), and scion dry weight to height ratio (WHR) were measured for the grafted tomato seedlings.

In order to minimize the location effects, the treatment locations in a controlled environment were randomly allocated. For statistical analyses, the SAS (Statistical Analysis System, V. 9.1, Cary, NC, USA) program was used to perform analysis of variance (ANOVA) and the Duncan multiple range test. Meanwhile, a randomized complete block with 3 replications and 9 seedlings in each replication was applied.

\subsection{Quantitative Real-Time PCR Analysis}

Total RNA was extracted from tomato leaves using the Easy-Spin Total RNA Extraction Kit (iNtRON Biotechnology, Seoul, Korea) and was used for cDNA synthesis by the GoScript Reverse Transcription System (Promega, Madison, WI, USA) according to the manufacturer's protocols. Gene expression was determined using the Rotor-Gene Q detection system (Qiagen, Hilden, Germany) with software (version 2.3.1). Reactions were performed in a $20-\mu \mathrm{L}$ total volume containing $1 \mu \mathrm{L}$ of cDNA, $0.5 \mu \mathrm{L}$ of each amplification primer $(10 \mu \mathrm{M})$ (Table S1), $10 \mu \mathrm{L}$ of $2 \times$ AMPIGENE qPCR Green Mix Lo-ROX (Enzo Life Sciences Inc., Farmingdale, NY, USA), and $8 \mu \mathrm{L}$ of dd $\mathrm{H}_{2} \mathrm{O}$ (double-distilled water). The relative expression of each gene was determined using the $2^{-\triangle \triangle \mathrm{Ct}}$ method, and $18 \mathrm{~S}$ was used as the reference gene.

\section{Results}

\subsection{Spectra of Different Supplementary Light Sources}

As shown in Figure 2, HPS has a high irradiance between 570 and $620 \mathrm{~nm}$ as well as between 820 and $830 \mathrm{~nm}$. MH has a relatively scattered spectrum between 350 and $820 \mathrm{~nm}$. FR has a high irradiance between 620 and $1050 \mathrm{~nm}$. $W$ is enriched at $420-475 \mathrm{~nm}$ and $500-650 \mathrm{~nm}$. Lastly, $W_{1} R_{2} B_{1}$ contains relatively monochromatic lights of $400-500 \mathrm{~nm}$ and $600-700 \mathrm{~nm}$.

\subsection{Growth and Development of Tomato Seedlings after Supplementary Light Treatments in Glasshouse}

The results showed that different light sources significantly affected the morphological characteristics of grafted tomato seedlings. The grafted seedlings of the two tomato cultivars grown in $W$ had the greatest scion length, followed by seedlings grown in $W_{1} R_{2} B_{1}, H P S$, and $M H$. Seedlings grown in FR and $C K$ had the shortest scions. Seedlings in $W_{1} R_{2} B_{1}$ had the greatest scion diameter, followed by those in W, HPS, and MH. CK and FR produced very thin and weak seedlings. The chlorophyll level (SPAD) was the lowest for seedlings grown in FR. Seedlings grown in the two LED treatments, especially those in $W_{1} R_{2} B_{1}$, had long roots with high fresh weights. $W_{1} R_{2} B_{1}$ also produced seedlings with the highest number of leaves and the greatest leaf quality (leaf length, width, and thickness) (Table 1).

The seedling morphology of tomato Super Sunload and Super Dotaerang affected by 10-day light treatments is shown in Figure 3. It can be clearly observed that $\mathrm{W}_{1} \mathrm{R}_{2} \mathrm{~B}_{1}$, followed by $\mathrm{W}$, were the most effective in promoting the level of root ball formation. The roots of seedlings grown in CK and FR were so weak that the seedlings could not be taken out together with the growing medium, as the roots could not wrap the medium in the plugs. 
Table 1. Effects of 10-day supplementary light treatments on growth and development of grafted tomato seedlings.

\begin{tabular}{|c|c|c|c|c|c|c|c|c|c|c|}
\hline \multirow{2}{*}{$\begin{array}{l}\text { Cultivar } \\
\text { (C) }\end{array}$} & \multirow{2}{*}{$\begin{array}{l}\text { Light Source } \\
\text { (LS) }\end{array}$} & \multicolumn{2}{|c|}{ Scion } & \multicolumn{5}{|c|}{ Leaf } & \multicolumn{2}{|c|}{ Root } \\
\hline & & $\begin{array}{l}\text { Length } \\
\text { (cm) }\end{array}$ & $\begin{array}{l}\text { Stem Diameter } \\
(\mathrm{mm})\end{array}$ & Number & $\begin{array}{l}\text { Length } \\
(\mathrm{cm})\end{array}$ & $\begin{array}{l}\text { Width } \\
\text { (cm) }\end{array}$ & $\begin{array}{l}\text { Thickness } \\
\text { (mm) }\end{array}$ & $\begin{array}{l}\text { Chlorophyll } \\
\text { (SPAD) }\end{array}$ & $\begin{array}{l}\text { Length } \\
\text { (cm) }\end{array}$ & $\begin{array}{c}\text { Fresh Weight } \\
\text { (g) }\end{array}$ \\
\hline & HPS & $20.2 a b^{z}$ & $6.15 a b c$ & $10.3 \mathrm{ab}$ & $12.7 \mathrm{a}$ & $9.0 \mathrm{a}$ & $0.49 \mathrm{~b}$ & $51.0 \mathrm{ab}$ & $12.6 \mathrm{a}$ & $0.95 \mathrm{ab}$ \\
\hline & $\mathrm{MH}$ & $18.9 \mathrm{ab}$ & $5.84 \mathrm{abc}$ & $9.3 \mathrm{bc}$ & $13.3 \mathrm{a}$ & $8.6 \mathrm{ab}$ & $0.55 \mathrm{ab}$ & $45.5 \mathrm{bc}$ & $15.3 \mathrm{a}$ & $1.18 \mathrm{ab}$ \\
\hline Super & FR & $15.5 \mathrm{~b}$ & $5.21 \mathrm{c}$ & $7.7 \mathrm{~d}$ & $10.9 \mathrm{bc}$ & $7.5 \mathrm{bc}$ & $0.47 \mathrm{~b}$ & $41.0 \mathrm{c}$ & $12.5 \mathrm{a}$ & $0.73 \mathrm{~b}$ \\
\hline \multirow{5}{*}{ Sunload } & W & $24.6 \mathrm{a}$ & $6.27 \mathrm{ab}$ & $11.0 \mathrm{a}$ & $13.5 \mathrm{a}$ & $8.5 \mathrm{ab}$ & $0.57 \mathrm{ab}$ & $57.0 \mathrm{a}$ & $14.7 \mathrm{a}$ & $1.37 \mathrm{a}$ \\
\hline & $\mathrm{W}_{1} \mathrm{R}_{2} \mathrm{~B}_{1}$ & $19.0 \mathrm{ab}$ & $6.55 \mathrm{a}$ & $11.0 \mathrm{a}$ & $12.6 \mathrm{ab}$ & $8.3 \mathrm{ab}$ & $0.68 \mathrm{a}$ & $56.8 \mathrm{a}$ & $15.7 \mathrm{a}$ & $1.41 \mathrm{a}$ \\
\hline & CK & $16.1 \mathrm{~b}$ & $5.33 \mathrm{bc}$ & $8.5 \mathrm{~cd}$ & $9.7 \mathrm{c}$ & $6.9 c$ & $0.45 \mathrm{~b}$ & $38.9 c$ & $8.1 \mathrm{~b}$ & $0.71 \mathrm{~b}$ \\
\hline & HPS & $17.2 \mathrm{~b}$ & $6.01 \mathrm{bc}$ & $9.8 \mathrm{ab}$ & $12.1 \mathrm{a}$ & $7.9 \mathrm{a}$ & $0.46 \mathrm{a}$ & $52.7 \mathrm{ab}$ & $13.4 \mathrm{ab}$ & $0.96 \mathrm{bc}$ \\
\hline & $\mathrm{MH}$ & $15.6 \mathrm{bc}$ & $5.87 \mathrm{bc}$ & $8.8 \mathrm{bc}$ & $11.2 \mathrm{ab}$ & $7.6 \mathrm{a}$ & $0.47 \mathrm{a}$ & $44.9 \mathrm{bc}$ & $11.1 \mathrm{~b}$ & $0.80 \mathrm{bc}$ \\
\hline Super & FR & $12.3 \mathrm{c}$ & $4.69 \mathrm{c}$ & $7.7 \mathrm{c}$ & $9.7 \mathrm{~b}$ & $5.7 \mathrm{~b}$ & $0.47 \mathrm{a}$ & $41.0 \mathrm{c}$ & $6.6 \mathrm{c}$ & $0.53 c$ \\
\hline \multirow[t]{3}{*}{ Dotaerang } & W & $23.3 \mathrm{a}$ & $6.38 \mathrm{~b}$ & $9.7 \mathrm{ab}$ & $11.6 \mathrm{ab}$ & $7.3 \mathrm{a}$ & $0.44 \mathrm{a}$ & $48.7 \mathrm{bc}$ & $11.9 \mathrm{ab}$ & $1.18 \mathrm{~b}$ \\
\hline & $\mathrm{W}_{1} \mathrm{R}_{2} \mathrm{~B}_{1}$ & $17.5 \mathrm{~b}$ & $7.86 \mathrm{a}$ & $11.2 \mathrm{a}$ & $12.3 \mathrm{a}$ & $7.8 \mathrm{a}$ & $0.58 \mathrm{a}$ & $61.0 \mathrm{a}$ & $14.8 \mathrm{a}$ & $1.79 \mathrm{a}$ \\
\hline & CK & $12.6 \mathrm{c}$ & $5.60 \mathrm{bc}$ & $7.3 \mathrm{c}$ & $9.8 \mathrm{~b}$ & $6.6 \mathrm{ab}$ & $0.51 \mathrm{a}$ & $43.1 \mathrm{c}$ & $7.6 \mathrm{c}$ & $0.57 \mathrm{c}$ \\
\hline \multicolumn{11}{|l|}{ F-test } \\
\hline LS & & $* * * y$ & $*$ & $* * *$ & $* * *$ & $* * *$ & * & $* * *$ & $* * *$ & $* * *$ \\
\hline C & & $* * *$ & NS & $*$ & $* * *$ & $* * *$ & $*$ & NS & $*$ & NS \\
\hline $\mathrm{LS} \times \mathrm{C}$ & & $* * *$ & $*$ & NS & NS & NS & $* *$ & $*$ & $* * *$ & $*$ \\
\hline
\end{tabular}




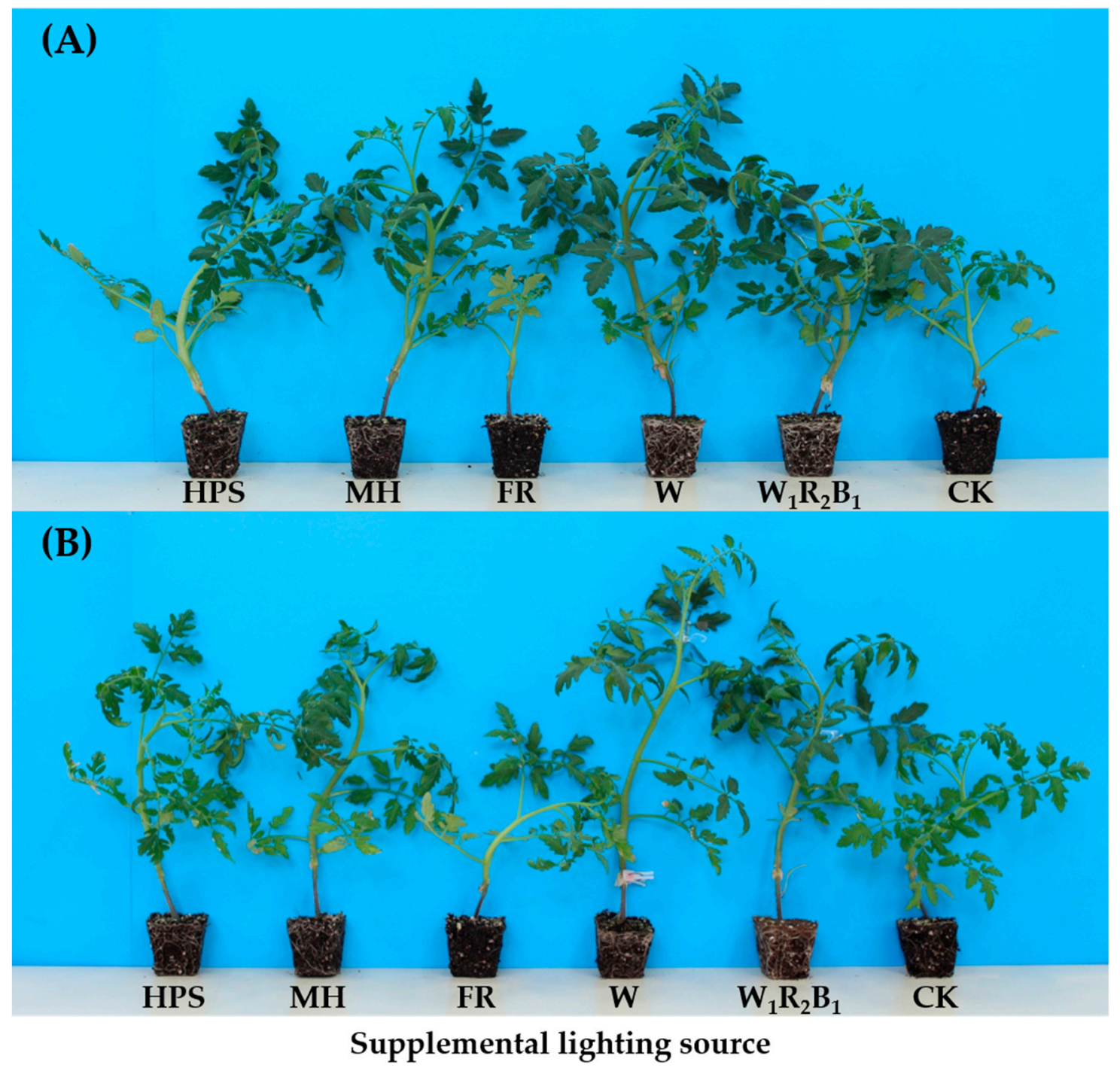

Figure 3. Effects of 10-day supplementary light treatments on morphology of grafted tomato seedlings Super Sunload (A) and Super Dotaerang (B).

\subsection{Biomass of Shoots and Roots}

The dry weights of the shoots and roots are shown in Figure 4. The seedlings grown in $W_{1} R_{2} B_{1}$ had the greatest scion dry weights. There were no significant differences in the dry weights of seedlings grown in HPS, MH, or W. Seedlings grown in FR and CK had very low scion dry weights. Seedlings grown in $W_{1} R_{2} B_{1}$ and $W$ had the greatest root dry weights, followed by those grown in HPS and MH. 

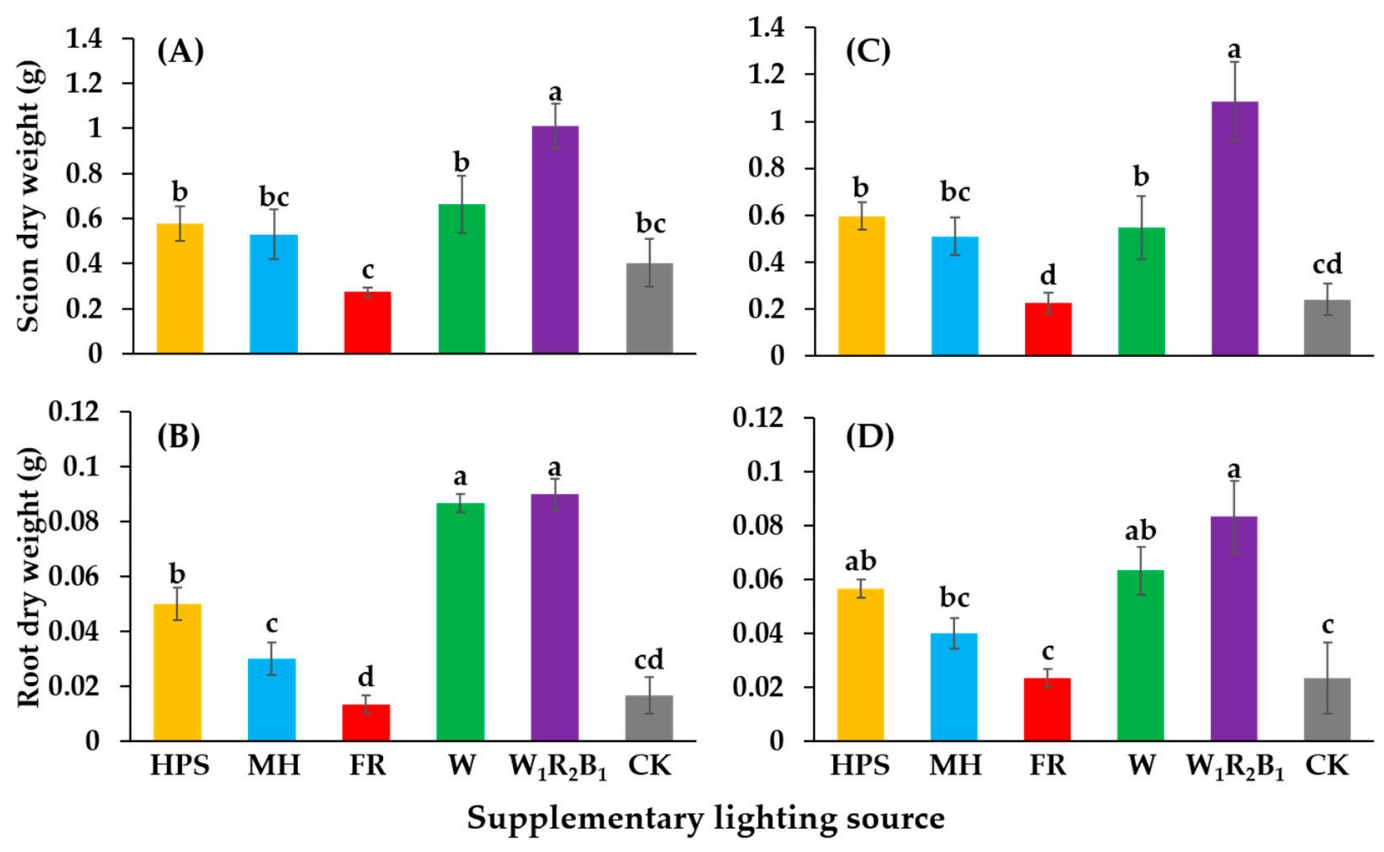

Figure 4. Effects of supplementary lighting on dry weights of the shoot and root of two tomato cultivars Super Sunload (A,B) and Super Dotaerang $(\mathbf{C}, \mathbf{D})$. The error bars represent the stand error $(n=9)$. Different letters indicate differences between treatments (ANOVA and Duncan's test, $p \leq 0.05$ ).

\subsection{Evaluation of Seedling Quality}

The qualitative objective of seedling production is to grow compact and sturdy seedlings. In order to assess the quality of the seedlings, the scion dry weight to height ratio (WHR) was calculated. The WHR of seedlings grown in $W_{1} R_{2} B_{1}$ was the greatest in this study (Figure $5 A, C$ ). Seedlings grown in $W_{1} R_{2} B_{1}$ also had the greatest specific leaf weight (SLW) (Figure $5 B, D$ ).

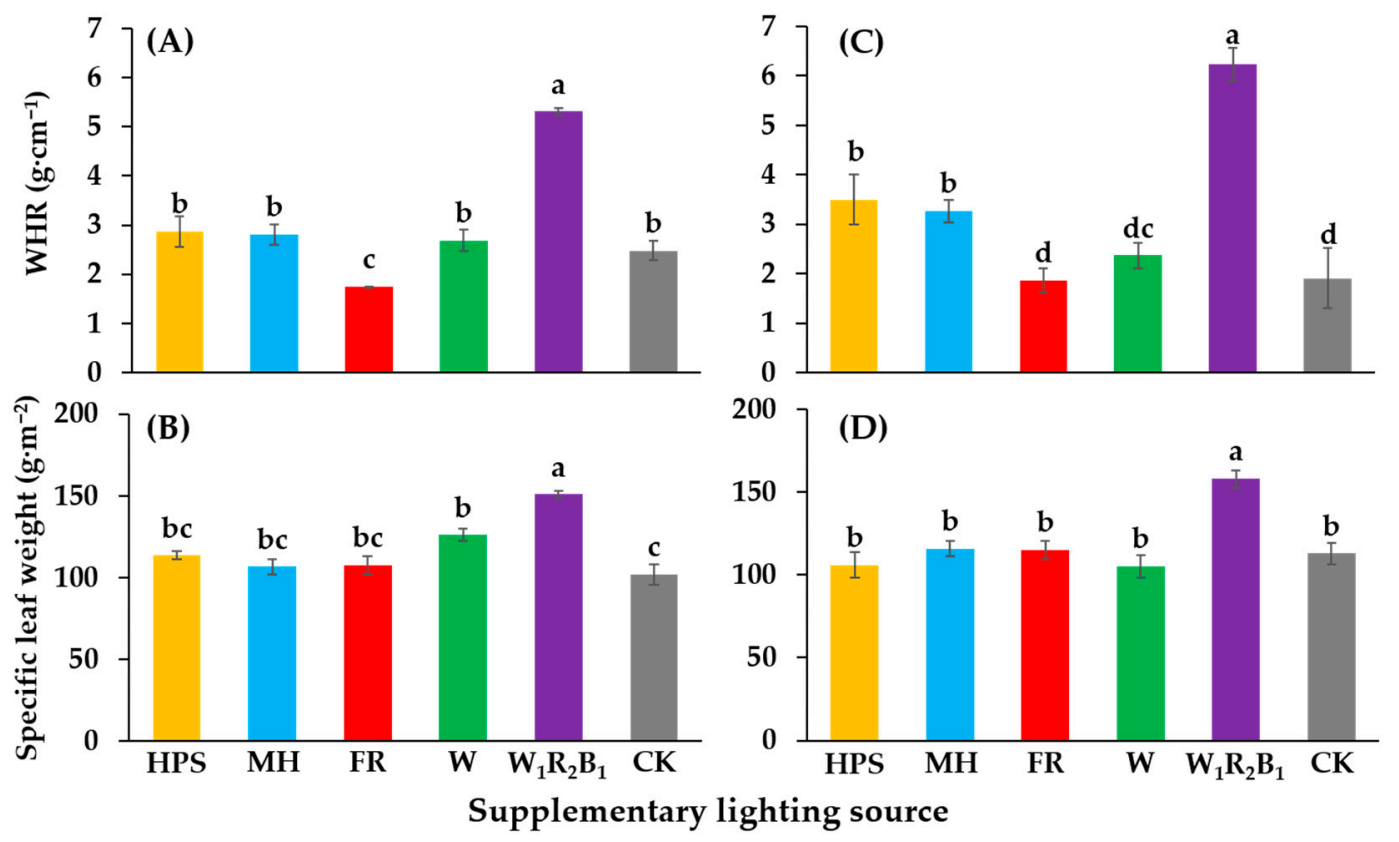

Figure 5. Effects of supplementary lighting on the WHR (scion dry weight to height ratio) and specific leaf weight of two tomato cultivars Super Sunload (A,B) and Super Dotaerang (C,D). The error bars represent the stand error $(n=9)$. Different letters indicate differences between treatments (ANOVA and Duncan's test, $p \leq 0.05)$. 


\subsection{Expression of Photosysthesis-Related Genes}

Genes encoding the PS I and PS II reaction center proteins were significantly affected by the different supplementary light sources (Figure 6). Generally, $W$ and $W_{1} R_{2} B_{1}$ enhanced the expression of $P s a A$ and $P s b A$, while FR had the opposite effect on the expression of the two genes. HPS had no significant influence on the expression of $P s a A$ and $P s b A$ when compared to CK. Interestingly, the relative expression of $P s a A$ in Super Sunload was increased 5.5- and 8.4-fold, while that of $P s b A$ was increased 10.9- and 3.1-fold under $W$ and $W_{1} R_{2} B_{1}$, respectively. It was also observed in Super Dotaerang that a dramatic increase of the expression of one gene resulted in a relatively lower increase in the expression of the other gene, and vice versa.
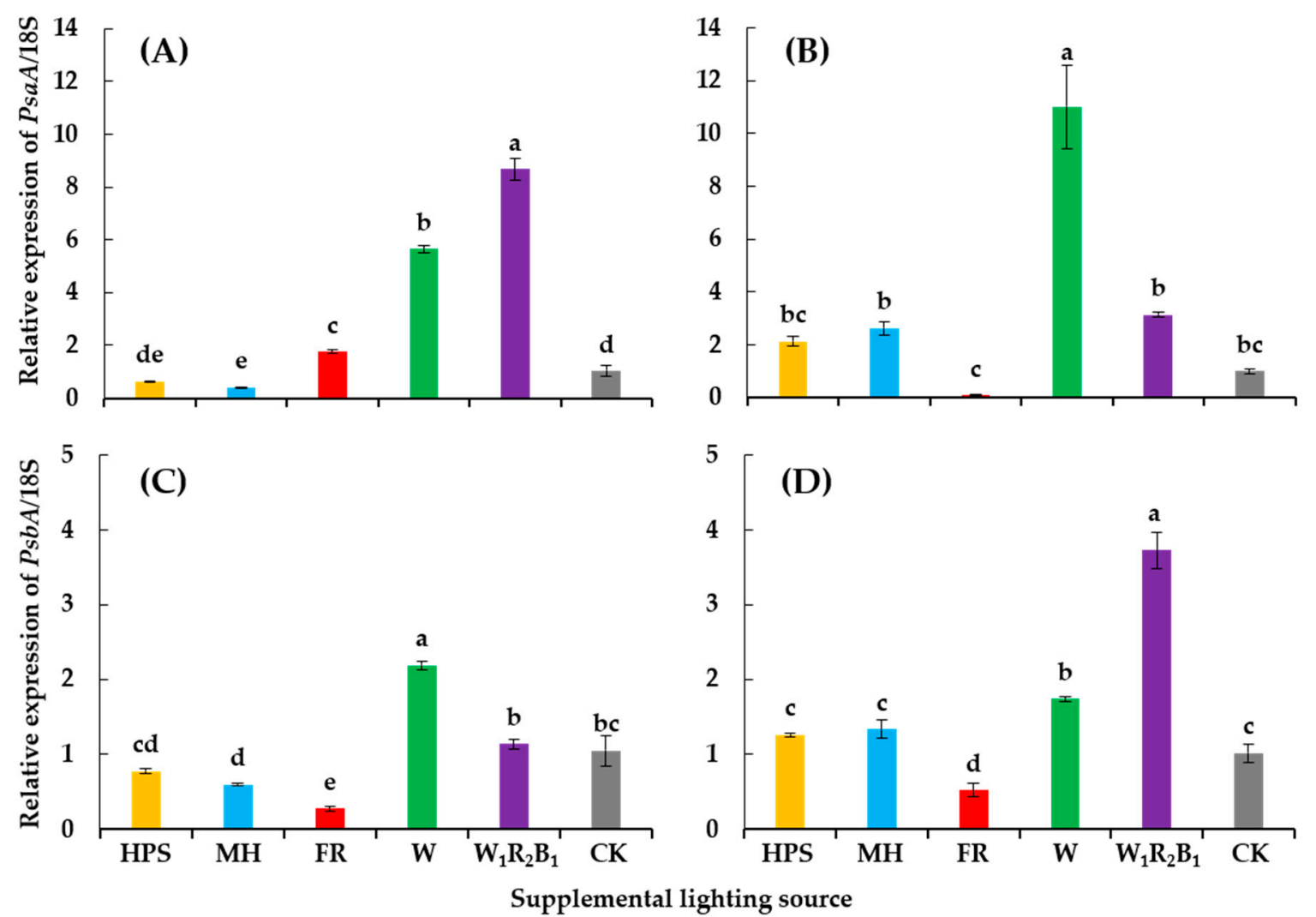

Figure 6. Relative expressions of $P_{s} a A$ and $P s b A$ in tomato cultivars Super Sunload $(\mathbf{A}, \mathbf{B})$ and Super Dotaerang $(\mathbf{C}, \mathbf{D})$. The error bars represent the stand error $(n=3)$. Different letters indicate differences between treatments (ANOVA and Duncan's test, $p \leq 0.05$ ).

\section{Discussion}

The chloroplast mainly absorbs R and B light for photosynthesis [19]. Our study considered the spectra of five commonly used light sources, and found that $W$ and $W_{1} R_{2} B_{1}$ had abundant $R$ and $B$ light. Moreover, grafted tomato seedlings developed well under $W$ and $W_{1} R_{2} B_{1}$. Previous studies have shown that $R$ light inhibits internode elongation and delays flower differentiation [20], and works on the accumulation of anthocyanins, chlorophyll, and carotenoids [21-23]. Moreover, R light helps plants resist biological and abiotic stresses [24]. In some cases, FR can counteract the effects of $R$ light [25]. Supplementary FR light can promote plant growth, which may be due to the increase in leaf area and the subsequent increase in light absorption [26]. For arabidopsis (Arabidopsis thaliana L.), plants grown in a lower R/FR condition had bigger leaves, higher biomass, and stronger resistance to low temperatures than those grown in a higher R/FR condition [27]. B light suppressed hypocotyl elongation and promoted cotyledon expansion in Arabidopsis thaliana. R light, on the other hand, promoted both the hypocotyl elongation and cotyledon expansion [28]. Furthermore, R light could 
help increase the plant biomass [29], while B light could inhibit lateral shoot growth and internode elongation to prevent excessive growth [30]. Therefore, the good development of tomato seedlings in $W$ and $W_{1} R_{2} B_{1}$ may be the result of sufficient $R$ and $B$ lights.

Numerous recent studies have shown that providing plants with single $\mathrm{R}$ or $\mathrm{B}$ light is insufficient to promote their photosynthesis and growth. Indeed, most studies suggest that combining $B$ and $R$ light is most effective in promoting the growth and development of plants. Lettuce (Lactuca sativa $\mathrm{L}$. Var. Capitata) had higher yields when grown under a combination of $\mathrm{R}$ and $\mathrm{B}$ lights than when grown under $\mathrm{R}$ light [31]. Batista et al. [32] reviewed the effects of light quality on plant tissue culture. Macedo et al. discovered that high-quality in vitro amaranthaceae (Alternanthera brasiliana Kuntze) could be obtained under a combination of B and R light [33]. Similarly, under light treatments of B, RB, and RBG, net photosynthesis and stomatal numbers per $\mathrm{mm}^{2}$ of cherry tomato leaves were significantly increased. Under RB, palisade tissue cells in leaves were especially well-developed and spongy tissue cells were localized in an orderly fashion [34]. The studies on mum (Chrysanthemum morifolium) showed that a combination of $\mathrm{R}$ and $\mathrm{B}$ light increased the net photosynthetic rate. The combination of $\mathrm{R}$ and $\mathrm{B}$ light could also maximize the dry weight and leaf area. On the contrary, the combination of $B, R$, and FR lights delayed the growth of chrysanthemum $[35,36]$. Jang et al. found that a mixture of $B$ and $R$ light was the most beneficial for healing and growing grafted pepper seedlings [37]. However, simply considering the traditionally used red and blue LEDs is not sufficient, and orange and green LEDs should be considered and tested when designing lighting systems [38]. In our previous study of grafted tomato seedlings treated with a combination of $R$ and $B$ light, and $W_{1} R_{2} B_{1}$, it was demonstrated that $W_{1} R_{2} B_{1}$ was the most suitable for developing vascular bundles and stomatal behaviors [39]. It was speculated that $\mathrm{W}$ light contains different wavelengths that provided plants with slightly different but essential lights.

Growers prefer stocky seedlings, as they are easy to transport and have a high survival rate after transplanting. Our results showed that $W_{1} R_{2} B_{1}$ best promotes the shoot and root biomass. Moreover, seedlings grown in $W_{1} R_{2} B_{1}$ had the highest WHR as they had more biomass and were shorter.

$P s a A$ and $P s b A$ are chloroplast genes encoding the P700 apoproteins of PS I and the D1 protein of PS II, respectively. The expression of $P s a A$ and $P s b A$ can regulate the plastid-encoded genes [40] as well as the nuclear genes [17]. Plastid-encoded and nuclear-encoded polymerases are interactional [13,17,41,42]. Therefore, the quality improvement of tomato seedlings under $\mathrm{W}_{1} \mathrm{R}_{2} \mathrm{~B}_{1}$ may be due to the up-regulation of $P s a A$ and $P s b A$. However, the reason for the different extents of up-regulation is yet unknown.

\section{Conclusions}

This study demonstrated that the root length, biomass, number of leaves, chlorophyll level (SPAD), scion dry weight to height ratio (WHR), and specific leaf weight (SLW) were the greatest for seedlings grown in $W_{1} R_{2} B_{1}$ among all considered treatments. The level of root ball formation was the greatest for seedlings grown in $W_{1} R_{2} B_{1}$, followed by those in $W, H P S$, and MH. Seedlings grown in FR were very thin and weak. The light spectra of $W$ and $W_{1} R_{2} B_{1}$ environments contained abundant $\mathrm{R}$ and $\mathrm{B}$ lights, which were largely absorbed and utilized by plants. The expression of PsaA and $P s b A$ indicated that their up-regulation might contribute to the improvement in the quality of tomato seedlings. Overall, the results suggest that $\mathrm{W}_{1} \mathrm{R}_{2} \mathrm{~B}_{1}$ is the most suitable light source for promoting the quality of grafted tomato seedlings.

Supplementary Materials: The following are available online at http:/ / www.mdpi.com/2073-4395/8/10/207/s1, Table S1: Sequences of primers used in this study.

Author Contributions: Conceptualization, B.R.J.; Methodology, B.R.J. and H.W.; Formal Analysis, J.H., C.L., J.Z., and M.W.; Resources, B.R.J.; Data Curation, H.W.; Writing-Original Draft Preparation, H.W.; Writing-Review \& Editing, B.R.J.; Project Administration, B.R.J.; Funding Acquisition, B.R.J., H.W., J.H., C.L., M.W., and D.I.K.

Funding: This research was funded by Korea Rural Development Administration, Project No. PJ012773022018. H.W., J.H., C.L., and M.W. were supported by a scholarship from the BK21 Plus Program, Ministry of Education, Korea. 
Acknowledgments: This work was carried out with the support of "Cooperative Research Program for Agriculture Science \& Technology Development (Project No. PJ012773022018)" Rural Development Administration, Korea. Hao Wei, Jiangtao Hu, Chen Liu, Mengzhao Wang, Jin Zhao, and Dongil Kang were supported by a scholarship from the BK21 Plus Program, Ministry of Education, Korea. HPS was provided by USHIO Korea, Inc.

Conflicts of Interest: The authors declare no conflict of interest.

\section{References}

1. Xu, D.; Gao, W.; Ruan, J. Effects of light quality on plant growth and development. Plant Physiol. J. 2015, 51, 1217-1234.

2. Long, S.P.; Zhu, X.G.; Naidu, S.L.; Ort, D.R. Can improvement in photosynthesis increase crop yields? Plant Cell Environ. 2006, 29, 315-330. [CrossRef] [PubMed]

3. Xu, D.Q.; Shen, Y.K. Photosynthetic efficiency and crop yield. In Handbook of Plant and Crop Physiology; Marcel Dekker: New York, NY, USA, 2002; pp. 821-834.

4. Patil, G.G.; Oi, R.; Gissinger, A.; Moe, R. Plant morphology is affected by light quality selective plastic films and alternating day and night temperature. Gartenbauwissenschaft 2001, 66, 53-60.

5. Murakami, K.; Matsuda, R.; Fujiwara, K. A basis for selecting light spectral distribution for evaluating leaf photosynthetic rates of plants grown under different light spectral distributions. Environ. Control Biol. 2017, 55, 1-6. [CrossRef]

6. Mitchell, C.A.; Dzakovich, M.P.; Gomez, C.; Lopez, R.; Burr, J.F.; Hernández, R.; Kubota, C.; Currey, C.J.; Meng, Q.; Runkle, E.S. Light-emitting diodes in horticulture. Hortic. Rev. 2015, 43, 1-87.

7. Gómez, C.; Morrow, R.C.; Bourget, C.M.; Massa, G.D.; Mitchell, C.A. Comparison of intracanopy light-emitting diode towers and overhead high-pressure sodium lamps for supplemental lighting of greenhouse-grown tomatoes. Hortic. Technol. 2013, 23, 93-98.

8. Buchalla, W.; Attin, T. External bleaching therapy with activation by heat, light or laser-A systematic review. Dent. Mater. 2007, 23, 586-596. [CrossRef] [PubMed]

9. Massa, G.D.; Kim, H.-H.; Wheeler, R.M.; Mitchell, C.A. Plant productivity in response to led lighting. Hortic. Sci. 2008, 43, 1951-1956.

10. Morrow, R.C. Led lighting in horticulture. Hortic. Sci. 2008, 43, 1947-1950.

11. Islam, M.A.; Kuwar, G.; Clarke, J.L.; Blystad, D.-R.; Gislerød, H.R.; Olsen, J.E.; Torre, S. Artificial light from light emitting diodes (LEDs) with a high portion of blue light results in shorter poinsettias compared to high pressure sodium (HPS) lamps. Sci. Hortic. 2012, 147, 136-143. [CrossRef]

12. Radkov, E.; Setlur, A.A. Full Spectrum Phosphor Blends for White Light Generation with Led Chips. U.S. Patent 790,679,0B2, 15 March 2011.

13. Dhingra, A.; Khurana, J.P.; Tyagi, A.K. Involvement of g-proteins, calmodulin and tagetitoxin-sensitive RNA polymerase in light-regulated expression of plastid genes ( $p s b A, p s a A$ and $r b c L$ ) in rice (Oryza sativa L.). Plant Sci. 2004, 166, 163-168. [CrossRef]

14. Muneer, S.; Park, Y.G.; Jeong, B.R. Red and blue light emitting diodes (LEDs) participate in mitigation of hyperhydricity in in vitro-grown carnation genotypes (Dianthus caryophyllus). J. Plant Growth Regul. 2018, 37, 370-379. [CrossRef]

15. Wang, Y.; Jensen, L.; Hojrup, P.; Morse, D. Synthesis and degradation of dinoflagellate plastid-encoded psbA proteins are light-regulated, not circadian-regulated. Proc. Natl. Acad. Sci. USA 2005, 102, 2844-2849. [CrossRef] [PubMed]

16. Trebitsh, T.; Levitan, A.; Sofer, A.; Danon, A. Translation of chloroplast $p s b A$ mRNA is modulated in the light by counteracting oxidizing and reducing activities. Mol. Cell. Boil. 2000, 20, 1116-1123. [CrossRef]

17. Leelavathi, S.; Bhardwaj, A.; Kumar, S.; Dass, A.; Pathak, R.; Pandey, S.S.; Tripathy, B.C.; Padmalatha, K.V.; Dhandapani, G.; Kanakachari, M.; et al. Genome-wide transcriptome and proteome analyses of tobacco $p s a A$ and $p s b A$ deletion mutants. Plant Mol. Boil. 2011, 76, 407-423. [CrossRef] [PubMed]

18. Lee, J.-M.; Kubota, C.; Tsao, S.; Bie, Z.; Echevarria, P.H.; Morra, L.; Oda, M. Current status of vegetable grafting: Diffusion, grafting techniques, automation. Sci. Hortic. 2010, 127, 93-105. [CrossRef]

19. Buschmann, C.; Langsdorf, G.; Lichtenthaler, H. Imaging of the blue, green, and red fluorescence emission of plants: An overview. Photosynthetica 2000, 38, 483-491. [CrossRef] 
20. Nanya, K.; Ishigami, Y.; Hikosaka, S.; Goto, E. In effects of blue and red light on stem elongation and flowering of tomato seedlings. Acta Hortic. 2012, 261-266. [CrossRef]

21. Lee, J.-G.; Oh, S.-S.; Cha, S.-H.; Jang, Y.-A.; Kim, S.-Y.; Um, Y.-C.; Cheong, S.-R. Effects of red/blue light ratio and short-term light quality conversion on growth and anthocyanin contents of baby leaf lettuce. J. Bio-Environ. Control 2010, 19, 351-359.

22. Liu, L.; Zabaras, D.; Bennett, L.; Aguas, P.; Woonton, B. Effects of UV-C, red light and sun light on the carotenoid content and physical qualities of tomatoes during post-harvest storage. Food Chem. 2009, 115, 495-500. [CrossRef]

23. Im, C.S.; Eberhard, S.; Huang, K.; Beck, C.F.; Grossman, A.R. Phototropin involvement in the expression of genes encoding chlorophyll and carotenoid biosynthesis enzymes and LHC apoproteins in chlamydomonas reinhardtii. Plant J. Cell Mol. Boil. 2006, 48, 1-16. [CrossRef] [PubMed]

24. Kreslavski, V.D.; Lyubimov, V.Y.; Shirshikova, G.N.; Shmarev, A.N.; Kosobryukhov, A.A.; Schmitt, F.J.; Friedrich, T.; Allakhverdiev, S.I. Preillumination of lettuce seedlings with red light enhances the resistance of photosynthetic apparatus to UV-A. J. Photochem. Photobiol. B 2013, 122, 1-6. [CrossRef] [PubMed]

25. Gordon, S.A.; Surrey, K. Red and far-red action on oxidative phosphorylation. Radiat. Res. 1960, 12, 325-339. [CrossRef] [PubMed]

26. Li, Q.; Kubota, C. Effects of supplemental light quality on growth and phytochemicals of baby leaf lettuce. Environ. Exp. Bot. 2009, 67, 59-64. [CrossRef]

27. Franklin, K.A.; Whitelam, G.C. Light-quality regulation of freezing tolerance in Arabidopsis thaliana. Nat. Genet. 2007, 39, 1410-1413. [CrossRef] [PubMed]

28. Whitelam, G.C.; Halliday, K.J. Annual Plant Reviews, Light and Plant Development; John Wiley \& Sons: Hoboken, NJ, USA, 2008; Volume 30.

29. Son, K.-H.; Oh, M.-M. Leaf shape, growth, and antioxidant phenolic compounds of two lettuce cultivars grown under various combinations of blue and red light-emitting diodes. Hortic. Sci. 2013, 48, 988-995.

30. Johkan, M.; Shoji, K.; Goto, F.; Hashida, S.-N.; Yoshihara, T. Blue light-emitting diode light irradiation of seedlings improves seedling quality and growth after transplanting in red leaf lettuce. Hortic. Sci. 2010, 45, 1809-1814.

31. Lin, K.-H.; Huang, M.-Y.; Huang, W.-D.; Hsu, M.-H.; Yang, Z.-W.; Yang, C.-M. The effects of red, blue, and white light-emitting diodes on the growth, development, and edible quality of hydroponically grown lettuce (Lactuca sativa L. Var. Capitata). Sci. Hortic. 2013, 150, 86-91. [CrossRef]

32. Batista, D.S.; Felipe, S.H.S.; Silva, T.D.; de Castro, K.M.; Mamedes-Rodrigues, T.C.; Miranda, N.A.; Ríos-Ríos, A.M.; Faria, D.V.; Fortini, E.A.; Chagas, K.; et al. Light quality in plant tissue culture: Does it matter? Cell. Dev. Biol.-Plant 2018, 54, 1-21. [CrossRef]

33. Macedo, A.F.; Leal-Costa, M.V.; Tavares, E.S.; Lage, C.L.S.; Esquibel, M.A. The effect of light quality on leaf production and development of in vitro-cultured plants of alternanthera brasiliana kuntze. Environ. Exp. Bot. 2011, 70, 43-50. [CrossRef]

34. Liu, X.; Guo, S.; Xu, Z.; Jiao, X.; Tezuka, T. Regulation of chloroplast ultrastructure, cross-section anatomy of leaves, and morphology of stomata of cherry tomato by different light irradiations of light-emitting diodes. Hortic. Sci. 2011, 46, 217-221.

35. Jeong, S.W.; Hogewoning, S.W.; van Ieperen, W. Responses of supplemental blue light on flowering and stem extension growth of cut chrysanthemum. Sci. Hortic. 2014, 165, 69-74. [CrossRef]

36. Jeong, S.W.; Park, S.; Jin, J.S.; Seo, O.N.; Kim, G.-S.; Kim, Y.-H.; Bae, H.; Lee, G.; Kim, S.T.; Lee, W.S.; et al. Influences of four different light-emitting diode lights on flowering and polyphenol variations in the leaves of chrysanthemum (Chrysanthemum morifolium). J. Agric. Food Chem. 2012, 60, 9793-9800. [CrossRef] [PubMed]

37. Jang, Y.; Mun, B.; Seo, T.; Lee, J.; Oh, S.; Chun, C. Effects of light quality and intensity on the carbon dioxide exchange rate, growth, and morphogenesis of grafted pepper transplants during healing and acclimatization. Korean J. Hortic. Sci. Technol. 2013, 31, 14-23. [CrossRef]

38. Lanoue, J.; Leonardos, E.D.; Grodzinski, B. Effects of light quality and intensity on diurnal patterns and rates of photo-assimilate translocation and transpiration in tomato leaves. Front. Plant Sci. 2018, 9, 756. [CrossRef] [PubMed]

39. Lee, K.M.; Lim, C.S.; Muneer, S.; Jeong, B.R. Functional vascular connections and light quality effects on tomato grafted unions. Sci. Hortic. 2016, 201, 306-317. [CrossRef] 
40. Khan, M.S.; Hameed, W.; Nozoe, M.; Shiina, T. Disruption of the $p s b A$ gene by the copy correction mechanism reveals that the expression of plastid-encoded genes is regulated by photosynthesis activity. J. Plant Res. 2007, 120, 421-430. [CrossRef] [PubMed]

41. Lezhneva, L.; Meurer, J. The nuclear factor hcf145 affects chloroplast $p s a A-p s a B-r p s 14$ transcript abundance in Arabidopsis thaliana. Plant J. 2004, 38, 740-753. [CrossRef] [PubMed]

42. Tozawa, Y.; Teraishi, M.; Sasaki, T.; Sonoike, K.; Nishiyama, Y.; Itaya, M.; Miyao, A.; Hirochika, H. The plastid sigma factor sig1 maintains photosystem I activity via regulated expression of the $p s a A$ operon in rice chloroplasts. Plant J. 2007, 52, 124-132. [CrossRef] [PubMed]

(C) 2018 by the authors. Licensee MDPI, Basel, Switzerland. This article is an open access article distributed under the terms and conditions of the Creative Commons Attribution (CC BY) license (http:/ / creativecommons.org/licenses/by/4.0/). 